25.47 (t, cyclopropane $\mathrm{CH}_{2}$ ), 36.49 (dd, $\mathrm{CH}_{2} \mathrm{C}=$ ), 41.41 (s, $\mathrm{CMe}_{3}$ ), 44.36 (d, NCH), $59.68(\mathrm{~s}, \mathrm{COH}, 87.83(\mathrm{~d}, \mathrm{CH}=\mathrm{C}), 163.32(\mathrm{~s}, \mathrm{NC}=)$, $203.73(\mathrm{~s}, \mathrm{C}=\mathrm{O})$; Mass spectrum, $m / e$ (relative abundance) 267 $\left(\mathrm{M}^{+}, 5\right), 250$ (5, OH.), 234 (15), 211 (10), 210 (85, $t$-Bu.), 192 (10), $\left.188(5), 182(5), 168(10), t-\mathrm{BuCOCH}=\mathrm{C}=\mathrm{N}^{+} \mathrm{HiPr}\right), 164(10), 153$ (10), $150(8), 126\left(100, t-\mathrm{BuCOCH}=\mathrm{C}=\mathrm{N}^{+} \mathrm{H}_{2}\right), 122(10), 112(10)$, $100(15), 99(30), 85(15), 84(30), 83(15), 68(8), 57\left(90, t-\mathrm{Bu}^{+}\right)$, 43 (15), 42 (15), 41 (35), 40 (10). Anal. Calcd: N, 5.23. Found: N, 5.11 .

Condensation of 2,2-Dimethyl-3,5-heptanedione (12) with Isopropylamine. A magnetically stirred mixture of $1.55 \mathrm{~g}(0.01$ $\mathrm{mol})$ of 2,2-dimethyl-3,5-heptanedione (12) and $2.34 \mathrm{~g}(0.04 \mathrm{~mol})$ of isopropylamine in $15 \mathrm{~mL}$ of benzene was treated dropwise either with $0.006 \mathrm{~mol}$ of titanium(IV) chloride (dissolved in $5 \mathrm{~mL}$ of pentane) or $0.03 \mathrm{~mol}$ of boron trifluoride etherate (dissolved in $5 \mathrm{~mL}$ of benzene). The reaction flask was protected with a calcium chloride tube. The reaction mixture was stirred for $1 \mathrm{~h}$, after which it was poured into $150 \mathrm{~mL}$ of aqueous $2 \mathrm{~N}$ sodium hydroxide. The organic phase was isolated and the aqueous layer was extracted twice with ether. The combined organic phases were dried $\left(\mathrm{Na}_{2} \mathrm{CO}_{3}\right)$ and evaporated in vacuo to afford enaminone 13 in $67 \%$ (using $\mathrm{TiCl}_{4}$ ) or $87 \%$ (using $\mathrm{BF}_{3} \cdot \mathrm{Et}_{2} \mathrm{O}$ ) yield: bp $125-27^{\circ} \mathrm{C}(15$ $\mathrm{mmHg}$ ); IR ( $\mathrm{NaCl}) 1610-1560 \mathrm{~cm}^{-1}$ (broad strong band, $\nu_{\mathrm{C}=0}$ ); ${ }^{1} \mathrm{H} \mathrm{NMR}\left(\mathrm{CDCl}_{3}\right) 1.13(9 \mathrm{H}, \mathrm{s}, t-\mathrm{Bu}), 1.22\left(6 \mathrm{H}, \mathrm{d}, J=6 \mathrm{~Hz}, \mathrm{Me}_{2}\right)$, $1.1\left(3 \mathrm{H}\right.$, covered by $t$-Bu signal, $\left.\mathrm{CH}_{3}\right), 2.26(2 \mathrm{H}, \mathrm{q}, J=7.5 \mathrm{~Hz}$, $\left.\mathrm{CH}_{2} \mathrm{C}=\right), 3.71(1 \mathrm{H}, \mathrm{m}, \mathrm{NCH}), 5.06(1 \mathrm{H}, \mathrm{s}, \mathrm{CH}=), 10.8(1 \mathrm{H}$, broad signal, NH); ${ }^{13} \mathrm{C} \mathrm{NMR}\left(\mathrm{CDCl}_{3}\right.$ ) 13.08 (q, Me), 24.22 (q, $\mathrm{Me}_{2}$ ), 25.23 (t, $\mathrm{CH}_{2}$ ), 28.12 (q, $\mathrm{Me}_{3}$ ), 41.25 (s, $\left.\mathrm{CMe}_{3}\right), 44.06$ (d, $\mathrm{NCH}$ ), 87.91 $(\mathrm{d}, \mathrm{CH}=), 167.50(\mathrm{~s}, \mathrm{NC}=), 203.34(\mathrm{~s}, \mathrm{C}=\mathrm{O})$; mass spectrum, $m / e$ (relative abundance) $197\left(\mathrm{M}^{+}, 8\right), 140(100), 122(8), 93(39), 57$ (17), 56 (17), 55 (8), 44 (15), 43 (23), 42 (16), 41 (35), 40 (9), 39 (8).

Reaction of Enaminone 2 with Sodium Methoxide in Methanol. A solution of $50 \mathrm{mg}(0.18 \mathrm{mmol})$ of enaminone 2 in
$0.4 \mathrm{~mL}$ of $1 \mathrm{~N}$ sodium methoxide in methanol was refluxed for $1 \mathrm{~h}$, after which the reaction mixture was poured into water and extracted three times with dichloromethane. The extracts were dried (sodium carbonate) and evaporated under vacuo to give a clear liquid residue. Although the product was more than $95 \%$ pure, an additional purification by preparative TLC (hexane/ether 80:20, silica gel $\mathrm{GF}_{254}$ (Merck)) provided an analytical sample of compound 14 (40 mg, $90 \%$ yield): $\mathrm{mp} 54{ }^{\circ} \mathrm{C} ;{ }^{1} \mathrm{H}$ NMR $\left(\mathrm{CDCl}_{3}\right)$ $1.10(9 \mathrm{H}, \mathrm{s}, t-\mathrm{Bu}), 1.20(9 \mathrm{H}, \mathrm{s}, t-\mathrm{Bu}), 1.20(6 \mathrm{H}, \mathrm{d}, J=6.5 \mathrm{~Hz}$, $\left.\mathrm{Me}_{2}\right), 3.43\left(2 \mathrm{H}, \mathrm{s}, \mathrm{CH}_{2}\right), 3.2-3.7(1 \mathrm{H}, \mathrm{m}, \mathrm{NCH}), 4.92(1 \mathrm{H}, \mathrm{s}$, $\mathrm{CH}=\mathrm{C}), 10.4\left(1 \mathrm{H}\right.$, broad, NH); ${ }^{13} \mathrm{C}$ NMR (CDCl $) 24.06$ (q, $\left.\mathrm{Me}_{2}\right)$, 27.46 (q, $\mathrm{Me}_{3}$ ), 27.96 (q, $\mathrm{Me}_{3}$ ), 40.66 (t, $\mathrm{CH}_{2}$ ), 41.31 (s, $\mathrm{CMe}_{3}$ ), 44.99 $\left(\mathrm{s}, \mathrm{CMe}_{3}\right), 45.37(\mathrm{~d}, \mathrm{NCH}), 90.86(\mathrm{~d},=\mathrm{CH}), 158.76(\mathrm{~s},=\mathrm{CN})$, 203.69 (s, $\mathrm{O}=\mathrm{CC}=\mathrm{C}$ ), $209.50\left(\mathrm{~s}, \mathrm{CH}_{2} \mathrm{C}=\mathrm{O}\right.$ ); IR ( NaCl) 1722 $\left(\nu_{t-\mathrm{Bu} O \mathrm{CH}_{2}}\right), 1605\left(\mathrm{br}, \nu_{t-\mathrm{BuCOCH}=\mathrm{CN}}\right), 3320 \mathrm{~cm}^{-1}\left(\mathrm{w}, \nu_{\mathrm{NH}}\right) ; \mathrm{MS}, m / e$ (relative abundance) $267\left(\mathrm{M}^{+}, 2\right), 211(3), 210(27), 126(6), 58$ (8), $57(100), 45(10), 44(5), 43(14), 42(8), 41$ (27), 40 (22). Anal. Calcd: N, 5.23. Found: N, 5.15 .

Acknowledgment. We are greatful to the "Commissariaat-Generaal voor de Internationale Culturele Samenwerking" (Belgium) for a postdoctoral research grant for one of us (Mariana Palamareva) and to the National Fund for Scientific Research for Financial support to the laboratory. We are also indebted to Prof. M. J. O. Anteunis, Laboratory of Organic Chemistry, NMR Spectroscopic Unit, Faculty of Sciences, State University of Gent, for recording the $360-\mathrm{MHz}{ }^{1} \mathrm{H}$ NMR spectrum.

Registry No. 1, 5950-19-6; 2, 97135-62-1; 12, 20734-29-6; 13, 97135-63-2;14,97135-64-3; 1-(1-chlorocyclohexyl)-1-ethanone, 1004-55-3; lithium diisopropylamide, 4111-54-0; pinacolone, 7597-8; ethyl propionate, 105-37-3; 3-bromo-3-methyl-2-butanone, 2648-71-7; lithium diethylamide, 816-43-3.

\title{
Modification of the Catalytic Activity of Zinc Chloride. A Kinetic Investigation in Zinc Chloride-Ether-Dichloromethane Mixtures
}

\author{
Herbert Mayr* and Wilhelm Striepe \\ Institut für Chemie der Medizinischen Universität zu Lübeck, Ratzeburger Allee 160, D-2400 Lübeck 1, \\ Federal Republic of Germany
}

Received December 28, 1984

\begin{abstract}
The addition reaction of chlorodiphenylmethane with 2-methyl-1-pentene was studied kinetically in order to characterize the catalytic activities of $\mathrm{ZnCl}_{2} / \mathrm{Et}_{2} \mathrm{O} / \mathrm{CH}_{2} \mathrm{Cl}_{2}$ mixtures of different composition. The activity of the heterogeneous $\mathrm{ZnCl}_{2} / \mathrm{CH}_{2} \mathrm{Cl}_{2}$ system is raised by 3-4 orders of magnitude when 0.5 equiv of ether are added. At $-70^{\circ} \mathrm{C}$ the system is homogeneous for $\left[\mathrm{Et}_{2} \mathrm{O}\right] /\left[\mathrm{ZnCl}_{2}\right]>1.1$, and the catalytic activity decreases with increasing ether/zinc chloride ratio. At $\left[\mathrm{Et}_{2} \mathrm{O}\right] /\left[\mathrm{ZnCl}_{2}\right]$ ratios greater than 2 , the reaction rate depends on the ether/zinc chloride ratio and is almost independent of the absolute concentration of the catalyst.
\end{abstract}

Zinc chloride is usually considered to be a weak Lewis acid. ${ }^{1}$ This view is essentially based on experiments carried out either under homogeneous conditions in donor solvents or under heterogeneous conditions in solvents like chlorinated hydrocarbons. In previous work we have found that addition reactions of chloroalkanes with alkenes, which are not efficiently catalyzed by zinc chloride in $e i$ ther dichloromethane or ether, readily take place in a mixture of these two solvents. ${ }^{2,3}$ In order to quantify this

(1) (a) Olah, G. A. Kobayashi, S. Tashiro, M. J. Am. Chem. Soc. 1972 94, 7448. (b) Olah, G. A. "Friedel-Crafts Chemistry"; Wiley-Interscience: New York, 1973. (c) Olah, G. A. "Friedel-Crafts and Related Reactions"; Wiley-Interscience: New York, 1963.

(2) (a) Mayr, H. Halberstadt, I K. Angew. Chem., Int. Ed. Engl. 1980, 19, 814. (b) Mayr, H.; Seitz, B.; Halberstadt-Kausch, I. K. J. Org. Chem. 1981, 46, 1041. (c) Klein, H.; Mayr, H. Angew. Chem., Int. Ed. Engl. 1981, 20, 1027. (d) Mayr, H.; Halberstadt-Kausch, I. K. Chem. Ber. 1982, 115, 3479. (e) Mayr, H.; Striepe, W. J. Org. Chem. 1983, 48, 1159. observation, we determined the rates of the zinc chloride catalyzed reactions of chlorodiphenylmethane (1) with 2-methyl-1-pentene (2) in dichloromethane-ether solutions of variable composition.

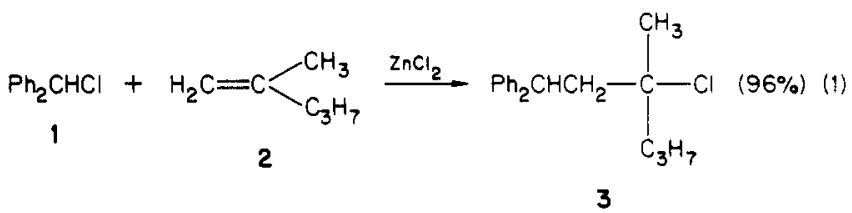

Experimental Section

Zinc chloride (commercial product, MERCK) was heated 48 $h$ at $160^{\circ} \mathrm{C}(0.01 \mathrm{mmHg})$ and stored in a nitrogen atmosphere.

(3) $\mathrm{ZnCl}_{2}-\mathrm{Et}_{2} \mathrm{O}-\mathrm{CH}_{2} \mathrm{Cl}_{2}$ has also successfully been used for acylations and alkoxyalkylations. (a) Tirpak, R. E.; Rathke, M. W. J. Org. Chem. 1982, 47, 5099. (b) Pindur, U.; Akgün, E. Synthesis 1984, 227. 


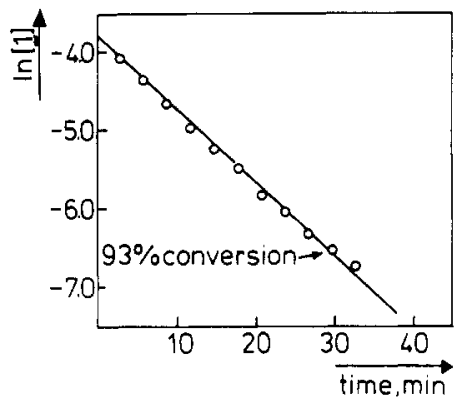

Figure 1. Decrease of [1] during the $\mathrm{ZnCl}_{2}-\mathrm{Et}_{2} \mathrm{O}$ catalyzed reaction of 1 with 2 .

Diethyl ether was predried over alumina (WOELM B Super I), refluxed over a sodium wire $(15 \mathrm{~h})$, and distilled in a nitrogen atmosphere. Dichloromethane was refluxed over $\mathrm{P}_{2} \mathrm{O}_{5}(20 \mathrm{~h})$ and distilled. Traces of phosphoric acid were removed by refluxing over a $\mathrm{Pb} / \mathrm{Na}$ alloy $(20 \mathrm{~h})$ and subsequent distillation. The purified solvent was stored over molecular sieves $(4 \AA)$. Chlorodiphenylmethane. Since commercial samples are usually contaminated by benzophenone, 1 was prepared by bubbling $\mathrm{HCl}$ into a suspension of diphenylmethanol $(60 \mathrm{~g})$ in petroleum ether $(100 \mathrm{~mL})$. 2-Methyl-1-pentene. The commercial product $(>99 \%$, FLUKA) was used without further purification.

3-Chloro-3-methyl-1,1-diphenylhexane (3). $1.5 \mathrm{~g}$ of $\mathrm{ZnCl}_{2}$ was dissolved in $1.8 \mathrm{~mL}$ of ether cooled at $-78^{\circ} \mathrm{C}$ and diluted with $50 \mathrm{~mL}$ of $\mathrm{CH}_{2} \mathrm{Cl}_{2}$. After addition of $4.05 \mathrm{~g}(20.0 \mathrm{mmol})$ of $1,1.78$ $\mathrm{g}(20.8 \mathrm{mmol})$ of 2 were added dropwise with stirring within 1 $\mathrm{h}$. The mixture was stirred for $1 \mathrm{~h}$ at $-78^{\circ} \mathrm{C}$, washed with aqueous ammonia, and dried with $\mathrm{CaCl}_{2}$. The solvent was evaporated and the remaining oil was distilled to give $5.5 \mathrm{~g}(96 \%)$ of $3:$ bp (bath) $155-160{ }^{\circ} \mathrm{C}(0.05 \mathrm{mmHg}) ; \mathrm{mp} 46-47{ }^{\circ} \mathrm{C} ;{ }^{1} \mathrm{H}$ NMR $(60 \mathrm{MHz}$, internal $\left.\mathrm{Me}_{4} \mathrm{Si}\right) \delta 0.78(\mathrm{br} \mathrm{t}, J=6 \mathrm{~Hz}, 3 \mathrm{H}), 1.30(\mathrm{~s}, 3 \mathrm{H}), 1.03-1.97$ $(\mathrm{m}, 7 \mathrm{H}), 2.58(\mathrm{~d}, J=6 \mathrm{~Hz}, 2 \mathrm{H}), 4.33(\mathrm{t}, J=6 \mathrm{~Hz}, 1 \mathrm{H}), 7.27$ $(\mathrm{s}, 10 \mathrm{H}) ;$ mass spectrum $(70 \mathrm{eV}), \mathrm{m} / e$ (relative intensity) 288 , $286\left(1.9,5.6, \mathrm{M}^{+}\right), 167(100)$. Anal. Calcd for $\mathrm{C}_{19} \mathrm{H}_{23} \mathrm{Cl}$ : C, 79.56; H, 8.08. Found: C, 79.04; H, 8.16.

Kinetic Experiments. Typical Procedure. A solution of $\mathrm{ZnCl}_{2}(1.00 \mathrm{~g}, 7.34 \mathrm{mmol})$ in ether $(1.61 \mathrm{~g}, 21.7 \mathrm{mmol})$ was diluted with $\mathrm{CH}_{2} \mathrm{Cl}_{2}$ to give $5 \mathrm{~mL}$. This solution was placed in a $100-\mathrm{mL}$ flask and cooled at $-70.0 \pm 0.2^{\circ} \mathrm{C}$ with nitrogen protection. A $\mathrm{CH}_{2} \mathrm{Cl}_{2}$ solution $(25 \mathrm{~mL})$ of nitrobenzene $(27.0 \mathrm{mg}$, HPLC standard), a $\mathrm{CH}_{2} \mathrm{Cl}_{2}$ solution $(20 \mathrm{~mL})$ of $2(2.10 \mathrm{~g}, 25.0 \mathrm{mmol})$, and $30 \mathrm{~mL}$ of $\mathrm{CH}_{2} \mathrm{Cl}_{2}$ were added and stirred until equalization of temperature took place $(\sim 15 \mathrm{~min})$. Finally, a solution of 1 $(0.500 \mathrm{~g}, 2.47 \mathrm{mmol})$ in $1 \mathrm{~mL}$ of $\mathrm{CH}_{2} \mathrm{Cl}_{2}$ was injected into the vigorously stirred solution. The volume of this solution decreased by $11 \%$ when cooled at $-70^{\circ} \mathrm{C}$.

At certain intervals, $\sim 0.5 \mathrm{~mL}$ of the solution were drawn into a syringe containing $2-3 \mathrm{~mL}$ of concentrated aqueous ammonia and shaken vigorously to destroy the catalyst. The two phases were allowed to separate in the syringe, and the organic layer was analyzed by HPLC (NUCLEOSIL $5 \mathrm{NO}_{2}, 5-\mu \mathrm{m}$ particles, isooctane-ether $=98: 2(\mathrm{v} / \mathrm{v}), 100 \mathrm{bar}$, flow $1.12 \mathrm{~mL} / \mathrm{min}$, detection at $254 \mathrm{~nm}$ ) to yield the composition of the reaction mixture as a function of time. If $\mathrm{NaOH}$ was utilized instead of $\mathrm{NH}_{3}$, the Lewis acid was not quenched instantaneously as indicated by deviations of individual points from the concentration/time correlation.

As shown in Figure 1, $\ln$ [1] gives a linear correlation with time and the pseudo-first-order rate constant $k_{1 \psi}$ can be evaluated from the slope of the straight line.

\section{Results and Discussion}

Homogeneous solutions of zinc chloride in ether can be obtained at $20^{\circ} \mathrm{C}$ if the molar ratio $\mathrm{Et}_{2} \mathrm{O} / \mathrm{ZnCl}_{2}$ is greater than 1.1. Solutions with a $\mathrm{Et}_{2} \mathrm{O} / \mathrm{ZnCl}_{2}$ ratio between 1.1 and 1.5 are very viscous and their preparation requires several hours of shaking. Precipitation of $\mathrm{ZnCl}_{2}$, which takes place when solutions with a $\mathrm{Et}_{2} \mathrm{O} / \mathrm{ZnCl}_{2}$ ratio $\$ 2$ are diluted with $\mathrm{CH}_{2} \mathrm{Cl}_{2}$ at room temperature, can be avoided if the $\mathrm{ZnCl}_{2}-$ ether complex is cooled at $-70^{\circ} \mathrm{C}$ prior to the addition of $\mathrm{CH}_{2} \mathrm{Cl}_{2}$.
Table I. Influence of Water on the Rate of the $\mathrm{ZnCl}_{2}-\mathrm{Et}_{2} \mathrm{O}$ Catalyzed Reaction of 1 with $2^{a}$

\begin{tabular}{cc}
\hline $\mathrm{H}_{2} \mathrm{O}, \mathrm{mmol}$ & $k_{1 \psi}, \mathrm{s}^{-1}$ \\
\hline 0.00 & $4.96 \times 10^{-4}$ \\
1.00 & $4.10 \times 10^{-4}$ \\
2.50 & $2.56 \times 10^{-4}$ \\
4.00 & $1.72 \times 10^{-4}$
\end{tabular}

a $7.34 \mathrm{mmol}$ of $\mathrm{ZnCl}_{2}(105 \mathrm{mmol} / \mathrm{L}), 21.7 \mathrm{mmol}$ of $\mathrm{Et}_{2} \mathrm{O}(311$ $\mathrm{mmol} / \mathrm{L}$ ), $2.47 \mathrm{mmol}$ of 1 , and $25.0 \mathrm{mmol}$ of 2 .

All kinetic studies of reaction 1 in homogeneous $\mathrm{ZnCl}_{2}-\mathrm{Et}_{2} \mathrm{O}-\mathrm{CH}_{2} \mathrm{Cl}_{2}$ systems gave linear $\ln [1] / t$ plots when 2 was employed in large excess over 1 . A first reaction order of 1 is thus indicated. Similarly a first reaction order of 2 can be derived from linear $\ln [3] / t$ plots, when 1 was used in great excess over 2 . In both cases, however, the reaction order of the excess compound was smaller than 1 and decreased with increasing concentration. Therefore, $k_{2}$ values cannot be calculated by dividing $k_{1 \psi}$ by the concentration of the excess compound. Comparable pseudo-first-order reaction constants were usually obtained by keeping the concentration of the major compound constant within a series of experiments.

The Effect of Moisture. Reproducibility of Rate Constants. The effect of water in Lewis acid catalyzed reactions seems to be rather obscure. Traces of water have been reported to be necessary in some Friedel-Crafts reactions whereas the catalyst is destroyed by larger amounts of water. ${ }^{1 b, c, 4}$ Quantitative data for the "water effect" in the zinc chloride-ether system were obtained by studying the rate of the model reaction (1) in the presence of definite amounts of water.

Table I shows that water somewhat retards the reaction. The effect of more than $4 \mathrm{mmol}$ of $\mathrm{H}_{2} \mathrm{O}$ was not determined because the mixture became inhomogeneous. Comparison of Tables I and II shows that the addition of water causes a similar retardation as the addition of equimolar amounts of ether. We, therefore, conclude that replacement of ether by water in the zinc complexes does not significantly influence their catalytic activity.

These data furthermore indicate that traces of water cannot considerably adulterate the reaction rates in homogeneous $\mathrm{ZnCl}_{2} / \mathrm{Et}_{2} \mathrm{O} / \mathrm{CH}_{2} \mathrm{Cl}_{2}$ systems. Consequently, we were able to reproduce the $k_{1 \psi}$ values within $\pm 7 \%$. Deviations up to $\pm 23 \%$ were observed, however, with $\mathrm{ZnCl}_{2}$ from different batches though identical drying procedures have regularly been applied. Deviations of $k_{1 \psi}$ values in different tables can be explained by that effect. Within each series of experiments, the same batch of $\mathrm{ZnCl}_{2}$ has been used. Zinc chloride, prepared from zinc and hydrogen chloride in anhydrous ether, ${ }^{5}$ was $10 \%$ more active than the best commercial product used.

Variation of the $\mathbf{E t}_{2} \mathbf{O} / \mathbf{Z n C l}_{2}$ Ratio. Table II and Figure 2 show that the rate of the model reaction 1 , catalyzed by a constant amount of $\mathrm{ZnCl}_{2}(102 \mathrm{mmol} / \mathrm{L})$, strongly depends on the ratio $\left[\mathrm{Et}_{2} \mathrm{O}\right] /\left[\mathrm{ZnCl}_{2}\right]$. For $\left[\mathrm{Et}_{2} \mathrm{O}\right]$ $=0$, i.e., heterogeneous $\mathrm{ZnCl}_{2}-\mathrm{CH}_{2} \mathrm{Cl}_{2}$ mixtures, nonlinear $\ln [1] /$ time plots were obtained, in contrast to the situation with ether containing systems. In three independent experiments with ether free systems, the slopes of the ln [1]/time plots increased by factors of 2.4-2.8 during the course of the reaction. Furthermore, the activity of $\mathrm{ZnCl}_{2}$ samples with different pretreatment differed up to a factor of 3 as indicated by the uncertainty region at the left edge of Figure 2.

(4) Petrov, A. A.; Leets, K. V. Zh. Obshch. Chim. 1956, 26, 1113; Chem. Abstr. 1956, 50, 11936d.

(5) Hamilton, R. T.; Butler, J. V. J. Chem. Soc. 1932, 2283. 
Table II. Influence of Ether on the Rate of the $\mathrm{ZnCl}_{2}$ Catalyzed Reaction of 1 with $2^{a}$

\begin{tabular}{ccc}
\hline $\mathrm{Et}_{2} \mathrm{O}, \mathrm{mmol}$ & {$\left[\mathrm{Et}_{2} \mathrm{O}\right] /\left[\mathrm{ZnCl}_{2}^{-}\right]$} & $k_{1 \psi}, \mathrm{s}^{-1}$ \\
\hline 0.0 & $0.0^{b, c}$ & $7.45 \times 10^{-6 d}$ \\
& & $\left(2.01 \times 10^{-5}\right)^{d}$ \\
0.0 & $0.0^{b, c}$ & $2.29 \times 10^{-5 d}$ \\
& & $\left(6.39 \times 10^{-5}\right)^{d}$ \\
0.0 & $0.0^{b, c}$ & $1.02 \times 10^{-5} d$ \\
1.61 & & $\left(2.43 \times 10^{-5}\right)^{d}$ \\
3.67 & $0.22^{b}$ & $1.73 \times 10^{-2 e}$ \\
7.34 & $0.50^{b}$ & $6.61 \times 10^{-2 e}$ \\
8.09 & $1.00^{b}$ & $4.80 \times 10^{-2 e}$ \\
10.8 & 1.10 & $3.95 \times 10^{-2 e}$ \\
11.6 & 1.47 & $1.82 \times 10^{-2 e}$ \\
13.5 & 1.58 & $8.88 \times 10^{-3 e}$ \\
16.2 & 1.84 & $5.35 \times 10^{-3 e}$ \\
18.9 & 2.21 & $1.66 \times 10^{-3}$ \\
21.7 & 2.57 & $7.05 \times 10^{-4}$ \\
24.4 & 2.96 & $4.96 \times 10^{-4}$ \\
27.1 & 3.32 & $2.98 \times 10^{-4}$ \\
28.4 & 3.69 & $1.27 \times 10^{-4}$ \\
29.8 & 3.87 & $9.82 \times 10^{-5}$ \\
32.5 & 4.06 & $8.61 \times 10^{-5}$ \\
35.2 & 4.43 & $4.72 \times 10^{-5}$ \\
40.6 & 4.79 & $3.27 \times 10^{-5}$ \\
56.8 & 5.53 & $1.73 \times 10^{-5}$ \\
& 7.73 & $4.59 \times 10^{-6}$ \\
& & \\
& & \\
\hline
\end{tabular}

a $7.34 \mathrm{mmol}$ of $\mathrm{ZnCl}_{2}(0.102 \mathrm{~mol} / \mathrm{L}), 2.47 \mathrm{mmol}$ of 1 , and 25.0 mmol of $2 .{ }^{b}$ Heterogeneous system. ${ }^{c} \mathrm{ZnCl}_{2}$ was stirred in $\mathrm{CH}_{2} \mathrm{Cl}_{2}$ for $24 \mathrm{~h}$ at $20^{\circ} \mathrm{C}$ before the reactants were added. ${ }^{d}$ These additions give nonlinear $\ln [1] /$ time plots. The first $k_{1 \psi}$ value corresponds to the slope at the initial stage of the reaction and the $k_{14}$ value in parentheses corresponds to the final stage. ${ }^{e}$ Experiments were carried out with $1.23 \mathrm{mmol}$ of 1 and $12.5 \mathrm{mmol}$ of 2 . The reported $k_{1 \psi^{-}}$values are corrected.

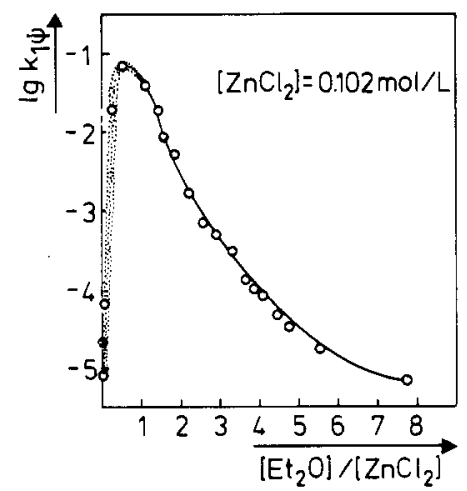

Figure 2. Rates of reaction 1 at constant zinc chloride concentration and variable $\left[\mathrm{Et}_{2} \mathrm{O}\right] /\left[\mathrm{ZnCl}_{2}\right]$ ratio.

Small amounts of ether raise the solubility of zinc chloride, resulting in a dramatic increase of the catalytic activity. The most active catalyst system $\left(\left[\mathrm{Et}_{2} \mathrm{O}\right] /\left[\mathrm{ZnCl}_{2}\right]\right.$ $\approx 0.5$ ), is $10^{3}$ to $10^{4}$ times more effective than the ether free $\mathrm{ZnCl}_{2}-\mathrm{CH}_{2} \mathrm{Cl}_{2}$ mixture. The exact position of the reactivity maximum cannot be determined since the system is heterogenous in this region.

More ether deactivates $\mathrm{ZnCl}_{2}$ by complexation, and at a ratio of $\left[\mathrm{Et}_{2} \mathrm{O}\right] /\left[\mathrm{ZnCl}_{2}\right] \gtrsim 4$ the activity drops below that of the ether free system.

Variation of the $\mathrm{ZnCl}_{2}-\mathrm{Et}_{2} \mathrm{O}$ Concentration at Constant $\left[\mathrm{Et}_{2} \mathbf{O}\right] /\left[\mathrm{ZnCl}_{2}\right.$ ] Ratios. At a constant $\left[\mathrm{Et}_{2} \mathrm{O}\right] /\left[\mathrm{ZnCl}_{2}\right]$ ratio of 1.84 , the pseudo-first-order rate constant $k_{1 \psi}$ increased by a factor of 1.7 when the $\mathrm{ZnCl}_{2}$ concentration was raised from 0.1 to $0.3 \mathrm{~mol} / \mathrm{L}$ (Table III). If the $\left[\mathrm{Et}_{2} \mathrm{O}\right] /\left[\mathrm{ZnCl}_{2}\right]$ ratio was kept constant at values between 2.5 and 4, variation of the total concentration of the catalyst over a wide range did not affect the reaction rates. For $\left[\mathrm{Et}_{2} \mathrm{O}\right] /\left[\mathrm{ZnCl}_{2}\right]=2.57$ the zinc chloride concentration was varied from 10.3 to $206 \mathrm{mmol} / \mathrm{L}$, while $k_{1 \psi}$
Table III. Variation of the Catalyst Concentration at Constant $\left[\mathrm{Et}_{2} \mathrm{O}\right] /\left[\mathrm{ZnCl}_{2}\right]$ Ratio

\begin{tabular}{cccc}
\hline $\mathrm{Et}_{2} \mathrm{O}, \mathrm{mmol}$ & $\mathrm{ZnCl}_{2}, \mathrm{mmol}$ & {$\left[\mathrm{Et}_{2} \mathrm{O}\right] /\left[\mathrm{ZnCl}_{2}\right]$} & $k_{1 \psi}, \mathrm{s}^{-1}$ \\
\hline 13.5 & 7.34 & 1.84 & $3.61 \times 10^{-3 a}$ \\
27.0 & 14.7 & 1.84 & $4.62 \times 10^{-3 a}$ \\
40.5 & 22.0 & 1.84 & $6.04 \times 10^{-3 a}$ \\
10.9 & 3.67 & 2.96 & $5.24 \times 10^{-4 b}$ \\
21.7 & 7.34 & 2.96 & $5.26 \times 10^{-4 b}$ \\
43.4 & 14.7 & 2.96 & $5.26 \times 10^{-4} b$ \\
65.1 & 22.0 & 2.96 & $5.55 \times 10^{-4} b$ \\
86.8 & 29.4 & 2.96 & $6.69 \times 10^{-4} b$ \\
29.4 & 7.34 & 4.00 & $9.12 \times 10^{-5 b}$ \\
58.7 & 14.7 & 4.00 & $7.92 \times 10^{-5 b}$ \\
88.1 & 22.0 & 4.00 & $8.68 \times 10^{-5 b}$ \\
1.88 & 0.73 & 2.57 & $2.25 \times 10^{-3 c}$ \\
4.72 & 1.83 & 2.57 & $2.36 \times 10^{-3 c}$ \\
9.44 & 3.67 & 2.57 & $2.39 \times 10^{-3} \mathrm{c}$ \\
18.9 & 7.34 & 2.57 & $2.18 \times 10^{-3 c}$ \\
28.3 & 11.0 & 2.57 & $2.11 \times 10^{-3 c}$ \\
37.8 & 14.7 & 2.57 & $2.39 \times 10^{-3 c}$ \\
75.5 & 29.4 & 2.57 & $5.07 \times 10^{-3 c}$
\end{tabular}

${ }^{a} 1.23 \mathrm{mmol}$ of 1 and $12.5 \mathrm{mmol}$ of $2 .{ }^{b} 2.47 \mathrm{~mol}$ of 1 and 25.0 $\mathrm{mmol}$ of 2 . ${ }^{\mathrm{c}} 24.7 \mathrm{mmol}$ of 1 and $2.50 \mathrm{mmol}$ of 2 .

was constant at $(2.25 \pm 0.15) 10^{-3} \mathrm{~s}^{-1}$. A further increase of the catalyst total concentration accelerated the reaction.

Presently we are unable to give an unequivocal interpretation of these findings because of the multiplicity of complex equilibria conceivable in this catalyst system. Since tetracoordination is of great importance in zinc chemistry, the following equilibrium may play a central role.

$$
\mathrm{ZnCl}_{2}\left(\mathrm{Et}_{2} \mathrm{O}\right)_{2} \stackrel{K}{=} \mathrm{ZnCl}_{2}\left(\mathrm{Et}_{2} \mathrm{O}\right)+\mathrm{Et}_{2} \mathrm{O}
$$

Our findings can be explained with the assumption that $K$ is relatively small and that the tricoordinated complex $\mathrm{ZnCl}_{2}\left(\mathrm{Et}_{2} \mathrm{O}\right)$ is the catalytically active species. On these premises, zinc chloride is almost completely tetracoordinated for $\left[\mathrm{Et}_{2} \mathrm{O}\right]_{0} /\left[\mathrm{ZnCl}_{2}\right]_{0}>2$, i.e.,

$$
\begin{gathered}
{\left[\mathrm{ZnCl}_{2}\left(\mathrm{Et}_{2} \mathrm{O}\right)\right] \text { very small }} \\
{\left[\mathrm{ZnCl}_{2}\left(\mathrm{Et}_{2} \mathrm{O}\right)_{2}\right] \approx\left[\mathrm{ZnCl}_{2}\right]_{0}} \\
{\left[\mathrm{Et}_{2} \mathrm{O}\right] \approx\left[\mathrm{Et}_{2} \mathrm{O}\right]_{0}-2\left[\mathrm{ZnCl}_{2}\right]_{0}}
\end{gathered}
$$

with

$$
\left[\mathrm{ZnCl}_{2}\left(\mathrm{Et}_{2} \mathrm{O}\right)\right]=\left[\frac{\left[\mathrm{ZnCl}_{2}\left(\mathrm{Et}_{2} \mathrm{O}\right)_{2}\right]}{\left[\mathrm{Et}_{2} \mathrm{O}\right]}=K \frac{\left[\mathrm{ZnCl}_{2}\right]_{0}}{\left[\mathrm{Et}_{2} \mathrm{O}\right]_{0}-2\left[\mathrm{ZnCl}_{2}\right]_{0}}\right.
$$

one can derive

$$
k_{1 \psi} \sim \frac{K}{\frac{\left[\mathrm{Et}_{2} \mathrm{O}\right]_{0}}{\left[\mathrm{ZnCl}_{2}\right]_{0}}-2}
$$

These considerations rationalize that at $\mathrm{Et}_{2} \mathrm{O} / \mathrm{ZnCl}_{2}$ ratios greater than 2 the reaction rates depend on the ratio $\mathrm{Et}_{2} \mathrm{O} / \mathrm{ZnCl}_{2}$ but not on the absolute $\mathrm{ZnCl}_{2}$ concentration. The zeroth order of $\left[\mathrm{ZnCl}_{2}\right]$ over a wide range of concentrations can thus be understood.

If the ether/zinc chloride ratio is altered (e.g., Table II) the relative importance of different complex equilibria changes. At low ether/zinc chloride ratios binuclear complexes, at high ratios, pentacoordinated complexes may become important. Equation 3 can, therefore, not be expected to cover the whole range of Table II. Though not very significant because of the small number of points, it is satisfactory that a linear correlation of $k_{1 \psi}$ with $1 /$ $\left(\left[\mathrm{Et}_{2} \mathrm{O}\right]_{0} /\left[\mathrm{ZnCl}_{2}\right]_{0}-2\right)$ is found for the three values with $2<\left[\mathrm{Et}_{2} \mathrm{O}\right] /\left[\mathrm{ZnCl}_{2}\right]<3$. 
Table IV. Pseudo-First-Order Rate Constants of $\mathrm{ZnCl}_{2}$-Catalyzed Reactions of 1 with 2 in Dichloromethane $\left(-70^{\circ} \mathrm{C}\right)$ in the Presence of Different Donors ${ }^{a}$

\begin{tabular}{lll}
\hline \multicolumn{1}{c}{ donor } & \multicolumn{1}{c}{$k_{1 \psi}, \mathrm{s}^{-1}$} & $k_{\text {rel }}$ \\
\hline diethyl ether & $1.02 \times 10^{-3}$ & 1.00 \\
ethyl acetate & $2.99 \times 10^{-4}$ & 0.29 \\
acetone & $2.49 \times 10^{-5}$ & 0.024 \\
tetrahydrofuran & $1.17 \times 10^{-6}$ & 0.0011 \\
tetrahydropyran & $4 \times 10^{-6}-4 \times 10^{-7}$ & $\sim 10^{-4}$ \\
dimethyl sulfoxide & no reaction & \\
pyridine & no reaction &
\end{tabular}

a $7.34 \mathrm{mmol}$ of $\mathrm{ZnCl}_{2}(0.103 \mathrm{~mol} / \mathrm{L}), 18.9 \mathrm{mmol}$ of donor, 2.47 mmol of 1 and $25.0 \mathrm{mmol}$ of $2 .{ }^{b}$ No first-order kinetics.

Other Donor Solvents. Some other $\mathrm{ZnCl}_{2}$ donor complexes which are soluble in $\mathrm{CH}_{2} \mathrm{Cl}_{2}$ have been examined with respect to their catalytic activity. At a donor $/ \mathrm{ZnCl}_{2}$ ratio of 2.57 , the ether complex exhibited the greatest relative catalytic activity (Table IV). The $\mathrm{Me}_{2} \mathrm{SO}$ and pyridine complexes are so stable that no reaction was observed at $-70{ }^{\circ} \mathrm{C}$.
Conclusion. Addition of ether increases the solubility of $\mathrm{ZnCl}_{2}$ in dichloromethane and thus enhances the catalytic activity of the Lewis acid. In systems with $\left[\mathrm{Et}_{2} \mathrm{O}\right]$ / $\left[\mathrm{ZnCl}_{2}\right] \approx 0.5$ the reactivity is $10^{3}-10^{4}$ times higher than in ether free systems. Reactions, which take more than 6 weeks in $\mathrm{ZnCl}_{2}-\mathrm{CH}_{2} \mathrm{Cl}_{2}$ systems, are complete within 1 $h$ if 0.5 equiv of ether are added! More ether reduces the catalytic activity of $\mathrm{ZnCl}_{2}$ because of complexation. The little sensitivity of the $\mathrm{ZnCl}_{2}-\mathrm{Et}_{2} \mathrm{O}$ system toward moisture facilitates its synthetic applications. Since a zeroth reaction order of $\left[\mathrm{ZnCl}_{2}\right]$ is found at $\left[\mathrm{Et}_{2} \mathrm{O}\right] /\left[\mathrm{ZnCl}_{2}\right]=2.5-4.0$ over a wide range of concentrations, an increase of the $\mathrm{ZnCl}_{2}-\mathrm{Et}_{2} \mathrm{O}$ quantity is usually not helpful to accelerate a reaction.

Acknowledgment. We thank the Deutsche Forschungsgemeinschaft and the Fonds der Chemischen Industrie for support of this work.

Registry No. 1, 2051-90-3; 2, 763-29-1; 3, 96761-10-3; $\mathrm{ZnCl}_{2}$ 7646-85-7.

\section{Notes}

\section{Concerning the Mechanism of Isomerization of cis-Azoalkanes \\ R. van Eldik, ${ }^{\text {1a }}$ H. Kelm, ${ }^{\text {la }}$ M. Schmittel, ${ }^{\text {,b }}$ and C. Rüchardt ${ }^{1 b}$ \\ Institute for Physical Chemistry, University of Frankfurt, 6000 Frankfurt am Main, and Chemical Laboratory, University of Freiburg, 7800 Freiburg. Federal Republic of Germany \\ Received November 23, 1984}

The mechanism of thermal decomposition of azoalkanes has been the subject of many investigations in recent years. Much of the discussion has focused on the unresolved question of whether a synchronous, two-bond cleavage process $\left(k_{\mathrm{s}}\right)$ or a two-step, one-bond cleavage process via short-lived diazenyl radicals $\left(k_{\mathrm{f}}<k_{\beta}+k_{\mathrm{d}}>k_{\mathrm{r}}\right)$ is operative (Scheme I) ${ }^{2,3}$ Neuman and co-workers ${ }^{4,5}$ have employed high pressure techniques to determine the volumes of activation for such processes and consider the latter to be a good mechanistic discriminator. They ${ }^{4,5}$ found typical values of between +12 and $+20 \mathrm{~cm}^{3} \mathrm{~mol}^{-1}$ for a two-step radical formation mechanism, compared to values of between +2 and $+5 \mathrm{~cm}^{3} \mathrm{~mol}^{-1}$ for synchronous two-bond scission processes. Preliminary investigations in our laboratories $^{6}$ on the pressure dependence of the thermal deazatization reactions of a series of trans-azoalkanes resulted in volumes of activation which fitted well into the two categories mentioned above, viz., $\mathrm{C}_{6} \mathrm{H}_{5} \mathrm{~N}=\mathrm{NC}(\mathrm{CN})_{2^{-}}$-

(1) (a) University of Frankfurt. (b) University of Freiburg.

(2) For an excellent review, see: Engel P. S. Chem. Rev. 1980, 88, 99.

(3) Engel, P. S.; Gerth, D. B. J Am. Chem. Soc. 1983, 105, 6849

(4) Neuman, R. C.; Binegar, G. A. J. Am. Chem. Soc. 1983, 105, 134 and references cited therein.

(5) Neuman, R. C.; Lockyer, G. D., Jr. J. Am. Chem. Soc. 1983, 105, 3982 .

(6) Palmer, D. A.; Kelm, H.; Lang, A.; Rüchardt, C., unpublished results. See: Lang, A. Ph.D. Dissertation, University of Freiburg, 1979.

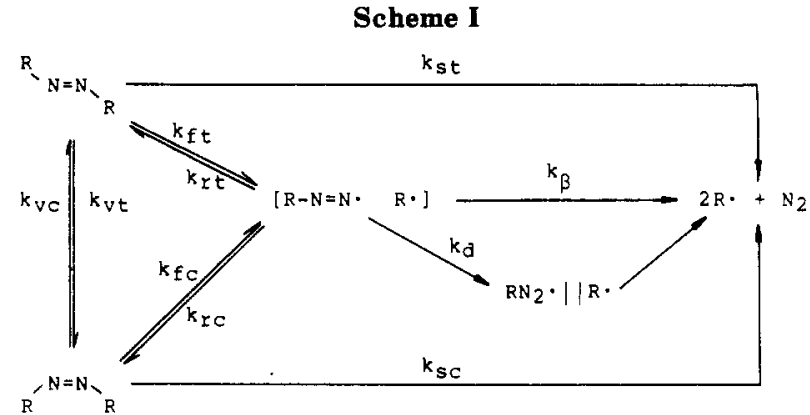

$v$ - inversion s - synchronous a diffusion

- radical pair recombination - radical pair formation - cis

$\mathrm{CH}_{3}, \Delta V^{*}=+11.9 \pm 0.8 ; \mathrm{C}_{6} \mathrm{H}_{5} \mathrm{C}\left(\mathrm{CH}_{3}\right)\left(\mathrm{C}_{2} \mathrm{H}_{5}\right) \mathrm{N}=\mathrm{NC}(\mathrm{C}-$ $\left.\mathrm{H}_{3}\right)\left(\mathrm{C}_{2} \mathrm{H}_{5}\right) \mathrm{CH}_{3}, \Delta V \ddagger=+12.8 \pm 2.3 ; \mathrm{NCC}\left(\mathrm{CH}_{3}\right)\left(\mathrm{C}_{2} \mathrm{H}_{5}\right) \mathrm{N}=$ $\mathrm{NC}\left(\mathrm{CH}_{3}\right)\left(\mathrm{C}_{2} \mathrm{H}_{5}\right) \mathrm{CN}, \Delta V^{*}=+2.9 \pm 0.5 \mathrm{~cm}^{3} \mathrm{~mol}^{-1}$. Recently, the possible participation of cis-azoalkanes during the deazatization of trans-azoalkanes has been suggested. $^{7-10}$ Theoretical MNDO calculations ${ }^{11}$ on the thermal decomposition of cis- and trans-azoethane and 1,1-diethyldiazene not only suggest that the step-wise mechanism is preferred to the synchronous two-bond cleavage process but also indicate that the cis transition state is common to both the cis and trans isomers, i.e., transazoethane first isomerizes and then looses $\mathrm{N}_{2}$.

Similarly the mechanism by which cis-azoalkanes isomerize thermally is a subject of great controversy. ${ }^{12}$ Various

(7) Schmittel, M.; Schulz; A. Rüchardt, C.; Hädicke, E. Chem. Ber. $1981,114,3533$

(8) Seeman, J. I.; Farone, W. A. J. Org. Chem. 1978, 43, 1854.

(9) Seeman, J. I. Chem. Rev. 1983, 83, 84.

(10) Flamm, M.; Beckhaus, H.-D.; Rüchardt, C. Tetrahedron Lett. $1982,23,1805$.

(11) Dannenberg, J. J. Rocklin, D. J. Org. Chem. 1982, 47, 4529. The authors postulate a hardly acceptable activation barrier of $10 \mathrm{kcal} \mathrm{mol}^{-1}$ for the recombination of the radical pair. 